\title{
Methodical Aspects of a Region's Economic Policy Diagnosis
}

\author{
Alyona Barinova \\ Department of Economics innovation and Finance \\ Vladimir state University named after A.G. and N. G. \\ Stoletovs \\ Vladimir, Russia \\ Alena_153@mail.ru

\section{Mikhail Barinov} \\ Department of International Relations \\ Department of strategic planning and management of \\ housing and communal complex \\ Vladimir state University named after A.G. and N. G. \\ Stoletovs \\ Vladimir, Russia \\ 3LF84@mail.ru
}

\author{
Anna Bezdudnaya \\ Head of the Department of Management and Innovation \\ St. Petersburg state University of Economics \\ St. Petersburg, Russia \\ annaspbru@yandex.ru
}

\author{
Aleksej Vasil'Chikov \\ Head of the Department of Economics of Construction and \\ Real Estate, Dean of the Faculty of Engineering and \\ Economics "Samara State Technical University" \\ Samara State Technical University \\ Samara, Russia \\ vav309@yandex.ru
}

\author{
Oksana Chechina \\ Department of industrial Economics and production management \\ Samara State Technical University \\ Samara, Russia \\ Chechinaos@yandex.ru
}

\begin{abstract}
The article presents approaches to the interpretation of the "regional economic policy" concept in a theoretical form. A fairly extensive debate regarding this category and assessment methods, confirms the interest of researchers in this study. The relevance of the article is determined by the objective features of the regional systems development. The goal of this study is to satisfy the need to diagnose regional economic policies based on the Gross Regional Product. The correlation and regression analysis method was used for such. The result is a criteria analysis of the regional economic policy with identification of key factors that influence it, which gives a more accurate economic description of the regions. A conclusion about the influence of a number of signs on the development of administrative-territorial formations and on the basis of which regional governments can plan and evaluate the features of the development of subjects is drawn.
\end{abstract}

Keywords: gross regional product, economic policy, region

\section{INTRODUCTION}

The problem field associated with economic growth has always been the focus of attention of domestic and foreign researchers, but it is worth noting that in modern realities this issue is considered at various methodological angles. A competent regional economic policy at the federal and especially regional levels is a tool for the transition to an innovative and reproductive type of development. Only with this approach it is possible to formulate a decision-making model based on a criteria-based assessment of socio-economic development, which allows to determine development priorities, both of regional systems and national as a whole.

In the context of modernizing various fields of activity, economic policy is a kind of an effective rod of state regulation, which, of course, should be based on a qualitative criteria-based assessment of the systems under study.

The purpose of this scientific research is the need to diagnose regional economic policies based on Gross Domestic Product.

To achieve this goal, it is necessary to solve a number of problems: 
However, it is impossible to make effective decisions, on a

- consider the theoretical and methodological interpretations of the concept of "regional economic policy";

- form a set of indicators to assess regional economic policy;

- build an economic-mathematical model, with the ability to predict the level of GRP.

The scientific originality of this studie's goal is to formulate a set of criteria that differs significantly in economic development with the construction of a model according to the North Caucasus Federal District.

\section{METHODS AND RESULTS}

The spectrum of statistical indicators that have a direct impact on economic policy is substantiated, followed by the selection of the key ones, by means of calculations made and the construction of a graphical interpretation - scatter diagrams.

\section{RESULTS}

The significance of the study lies in the selection and justification of criteria that evaluates the economic development of the subjects of the North Caucasus Federal District with the construction of a mathematical forecasting model.

\section{DISCUSSION}

Regional economic policy in modern conditions represents an effective tool, a mechanism of state regulation. The authors considered a number of scientific approaches to the interpretation of regional economic policy. The researchers Popodko G.I. and Nagaeva O.S. consider regional policy as a set of resources that must be effectively redistributed within the country to achieve the goals set [1]. If we consider the interpretation enshrined in the document of the Government of the Russian Federation, then it is understood as a set of goals, tasks set before executive authorities and aimed at managing, stimulating the socio-economic development of the country and its subjects [2].

Another point of view of other researchers regarding the consideration of regional economic policy also deserves attention. Their peculiarity, in their opinion, is that this type of policy is interpreted not only from the position of state management of the economic sphere in the regions, but also by the possibility of inter-regional self-regulation. Gladky Yu.N., Chistobaev A.I. believe that regional policy reflects the relationship between state executive authorities in the economic, political, social and other spheres in the spatial aspect [3]. Marusinina E. Yu., Moseyko V.O., Epinina V.S. and Korobov S.A. [4] agree with them. In the general understanding, according to Nosov S.S. Regional economic policy (REP) is a set of tools, methods that affect the processes of territory development in a particular area and determine three levels of its implementation: municipal, subfederal, and federal [5]. regional level including, without reliable information giving a quantitative assessment of phenomena, indicators that reflect key aspects of the development of territories.

A quantitative assessment of regional policy was made and presented in the scientific works of L.A. Valitova [6], E.G. Vasilyeva [7], A.N. Ostroumova [8], O.F. Ostroumova and several others [9-13].

Keep your text and graphic files separate until after the text has been formatted and styled. Do not use hard tabs, and limit use of hard returns to only one return at the end of a paragraph. Do not add any kind of pagination anywhere in the paper. Do not number text heads-the template will do that for you.

Regional economic policy trends can be determined on the basis of an effective indicator which stands for GRP [14]. The North Caucasian Federal District was chosen as the object of study as of 2016. A system of statistical indicators was formed based on the data of the Federal State Statistics Service and an econometric analysis of factors was performed with the construction of regression equations, which in the future will allow predicting the variability of the phenomena. To achieve this goal, a number of indicators were selected that characterize the economic aspect of regional policy and only a few of them were selected based on the results of correlation analysis that meet the requirements of tight connection with GRP of more than 0.8 and statistical significance of more than $5 \%$ ( $p \leq 0.05$ ), which is sufficient justification for their selection. Other factors influencing the economic sphere could be added to the selected factors, however, only those were selected that characterize the effectiveness of economic policy and were selected based on the results of correlation and regression analysis, with a tightness of connection (with GRP) of more than 0.8 for each of them and the level of statistical significance $p \leq 0.05$, which is an undoubted argument for the reliability of the selected criteria. The initial data for the calculations is presented in table 1 .

In order to justify the factors included in the econometric model, at the preliminary stage of calculations, a pair correlation analysis of factor attributes $X$ was performed, which allows to eliminate the values related to each other.

An econometric analysis showed that there is a statistically significant and strong relationship between the factors $X_{2}, X_{4}$, $X_{5}, X_{6}$ and $X_{7}$. Therefore, only indicators $X_{1}$ and $X_{3}$ were selected and, therefore, if, according to these characteristics, we obtain a significance that does not exceed the permissible limits (up to 5\%), then their inclusion in the linear regression model will be justified. Based on the obtained experimental data of regression analysis (see table 2 ), we conclude that the factors $X_{I}(p=0.0272)$ and $X_{3}(p=0.0068)$ are significant. 
TABLE II. LINEAR REGRESSION ANALYSIS RESULTS FOR A $X_{1}, X_{3}$ AND $Y$

TABLE I. INDICATORS CHARACTERIZING / INFLUENCING REP

\begin{tabular}{|c|c|c|c|c|c|c|c|c|}
\hline \multirow[b]{2}{*}{ 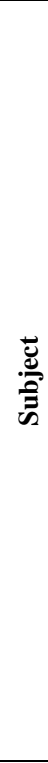 } & \multicolumn{8}{|c|}{ Indicator and its value (for 2016) } \\
\hline & $\begin{array}{c}\text { GRP } \\
(\text { milli } \\
\text { on } \\
\text { ruble } \\
\text { s) }\end{array}$ & $\begin{array}{c}\text { The } \\
\text { numb } \\
\text { er of } \\
\text { foreig } \\
n \\
\text { citize } \\
\text { ns } \\
\text { holdi } \\
\text { ng a } \\
\text { paten } \\
\text { tfor } \\
\text { work } \\
\text { (peop } \\
\text { le) } \\
\\
\end{array}$ & $\begin{array}{c}\text { The } \\
\text { numb } \\
\text { er of } \\
\text { empl } \\
\text { oyees } \\
\text { of } \\
\text { state } \\
\text { and } \\
\text { local } \\
\text { autho } \\
\text { rities } \\
\text { (peop } \\
\text { le) } \\
\\
\\
\\
\\
\end{array}$ & $\begin{array}{c}\text { Costs } \\
\text { of } \\
\text { the } \\
\text { conso } \\
\text { lidate } \\
d \\
\text { budg } \\
\text { ets of } \\
\text { consti } \\
\text { tuent } \\
\text { entiti } \\
\text { es of } \\
\text { the } \\
\text { Russi } \\
\text { an } \\
\text { Feder } \\
\text { ation } \\
\text { (milli } \\
\text { on } \\
\text { ruble } \\
\text { s) } \\
X 3\end{array}$ & $\begin{array}{c}\text { Fixed } \\
\text { invest } \\
\text { ment } \\
\text { (milli } \\
\text { on } \\
\text { ruble } \\
\text { s) } \\
\end{array}$ & $\begin{array}{c}\text { Resea } \\
\text { rch } \\
\text { and } \\
\text { devel } \\
\text { opme } \\
\text { nt } \\
\text { organ } \\
\text { izatio } \\
\text { ns }\end{array}$ & $\begin{array}{c}\text { Num } \\
\text { ber of } \\
\text { resea } \\
\text { rcher } \\
\text { s with } \\
\text { an } \\
\text { acade } \\
\text { mic } \\
\text { degre } \\
\text { e } \\
(\text { peop } \\
\text { le) } \\
\\
\end{array}$ & $\begin{array}{c}\text { Dome } \\
\text { stic } \\
\text { resea } \\
\text { rch } \\
\text { and } \\
\text { devel } \\
\text { opme } \\
\text { nt } \\
\text { costs } \\
(\text { milli } \\
\text { on } \\
\text { ruble } \\
\text { s) } \\
\end{array}$ \\
\hline $\begin{array}{l}\mathrm{S} \\
1\end{array}$ & $\begin{array}{l}\text { ¿े } \\
\text { oे } \\
\text { مे } \\
\text { in }\end{array}$ & 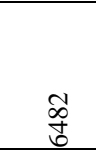 & $\begin{array}{l}\vec{\infty} \\
\stackrel{m}{m}\end{array}$ & 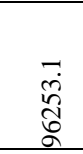 & 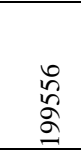 & f & త్రి & $\hat{\grave{\Omega}}$ \\
\hline $\begin{array}{l}S \\
2\end{array}$ & $\begin{array}{l}\hat{i} \\
\infty \\
\infty \\
\stackrel{0}{n} \\
n\end{array}$ & 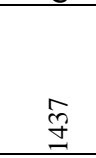 & $\underset{\infty}{\mathbb{\infty}}$ & 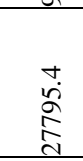 & రి & n & 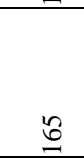 & $\begin{array}{l}\infty \\
\infty \\
0 \\
0\end{array}$ \\
\hline $\begin{array}{l}\mathrm{S} \\
3\end{array}$ & 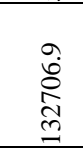 & 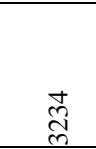 & 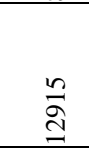 & 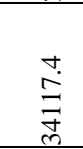 & तె & $\stackrel{\infty}{-}$ & $\underset{\stackrel{\infty}{\circ}}{\circ}$ & 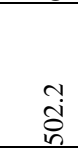 \\
\hline $\begin{array}{l}\mathrm{S} \\
4\end{array}$ & $\frac{m}{\frac{m}{n}}$ & $\begin{array}{l}\frac{N}{m} \\
m\end{array}$ & ஜ̊ হু & 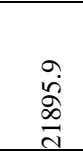 & $\begin{array}{l}n \\
\tilde{c} \\
\tilde{c}\end{array}$ & $\Xi$ & $\underline{6}$ & 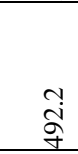 \\
\hline $\begin{array}{l}\mathrm{S} \\
5\end{array}$ & 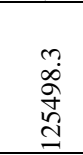 & $\underset{\sigma}{\mathbb{\sigma}}$ & $\begin{array}{l}n \\
\tilde{b} \\
+1\end{array}$ & 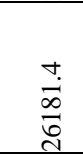 & $\begin{array}{l}\hat{n} \\
\tilde{n} \\
\tilde{n}\end{array}$ & 4 & ఏ & $\underset{n}{\vec{n}}$ \\
\hline $\begin{array}{l}S \\
6\end{array}$ & 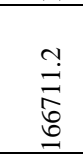 & $\underset{\infty}{\stackrel{\infty}{0}}$ & 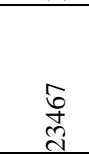 & 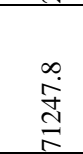 & $\begin{array}{l}\text { fo } \\
\text { है } \\
\text { d }\end{array}$ & $\infty$ & $\begin{array}{l}\mathscr{b} \\
d \\
d\end{array}$ & $\begin{array}{l}\infty \\
\frac{\infty}{N}\end{array}$ \\
\hline $\begin{array}{l}S \\
7\end{array}$ & 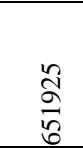 & ڤे & $\frac{\text { సे }}{\text { ले }}$ & 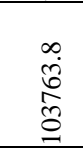 & $\begin{array}{l}\text { ホ̀ } \\
\text { ปิ } \\
\text { İ }\end{array}$ & g & 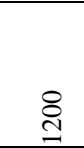 & $\stackrel{\infty}{\infty}$ \\
\hline & ote** & 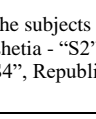 & 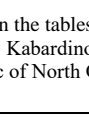 & ri & & 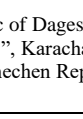 & $\mathrm{R}$ & $\begin{array}{l}\text { public of } \\
\text { epublic } \\
\text { Stavropol } \\
\text { on- "S7". }\end{array}$ \\
\hline
\end{tabular}

\begin{tabular}{|l|l|l|l|l|l|}
\hline № & Indicator & $\begin{array}{c}\text { Coefficien } \\
\mathbf{t} \\
\text { parameter }\end{array}$ & $\begin{array}{c}\text { Regressio } \\
\mathbf{n} \text { Model } \\
\text { Standard } \\
\text { Error }\end{array}$ & $\begin{array}{c}t- \\
\text { Student's } \\
\text { criteria }\end{array}$ & $\begin{array}{c}\text { Level of } \\
\text { Statistical } \\
\text { significan } \\
\text { ce } p\end{array}$ \\
\hline 1 & Free term & -160125 & 46077.39 & -3.47514 & 0.025464 \\
\hline 2 & $X_{1}$ & 51 & 14.99 & 3.40015 & 0.027274 \\
\hline 3 & $X_{3}$ & 5 & 0.1 & 5.12554 & 0.0068 \\
\hline
\end{tabular}

The value of the Fisher criteria at a given level of significance reflects how well this model explains the overall variance of the dependent variable [15]. Regression coefficients are recognized as statistically significant and the equation is true if the calculated $\left(t_{\text {calc }}\right)$ value $F$ exceeds the tabular $\left(t_{\text {tabl }}\right)$ value $t$ for a given level of significance $p$ and $n-k-1$ degrees of freedom [16], which is observed in our case. According to calculations, the significance of the Fisher criterion for $X_{1}(F=13.39)$ significantly exceeds the tabular value $(F=6.61)$, and, similarly, for the factor attribute $X_{3}$ $(F=30.78)$ compared to it. This fact indicates that the explained variance is significantly larger than the unexplained, and the linear regression model is significant.

It is to be noted that the result of the calculations is the conclusion that it is possible to use selected indicators to build a high-quality regression model that affects GRP and, consequently, the economic policy of a particular subject. There is also a correlation of the "number of foreign citizens holding a patent for labor activity" with GRP, which is quite logical, because additional attraction of labor, creating a finished product on the territory of the subject contributes to the overall growth of the GRP. However, tax payments to the budget (from the salaries of workers and to social funds by the employer) are paid only to persons officially employed, therefore, it is necessary for the Federal Migration Service authorities to stop the activities of unscrupulous citizens who do not have official employment and registration. Expenses of the consolidated budgets of the constituent entities of the Russian Federation also affect the growth of GRP, since they can be associated with the support of small and medium-sized enterprises, as well as financing the educational sector, which provides training for competent specialists in a particular industry, which will further improve the quality of labor resources, the absence of their scarcity, the growth of labor productivity, the quality of goods, work, services and directly the growth of GRP.

Therefore, the resulting dependence can be represented as a qualitative model (1):

$$
Y=-160125+51 * X_{1}+5 * X_{3}
$$

and a graphical interpretation of the correlation is reflected in the scatterplot (see fig. 1). 
improving the social and economic situation in the country [17].

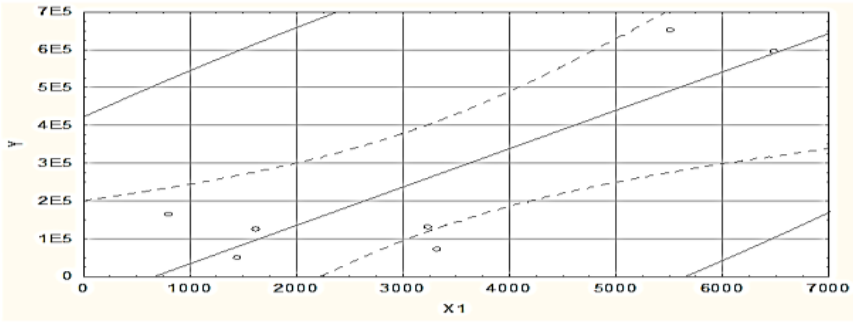

Fig. 1. Graphical representation of linear regression dependence of $Y$ to $X^{I}$ for 2016

Based on the econometric model created (1), its validity was checked according to the data of the Stavropol Region. Factors data for the year 2015 was used for such and a forecast for the year 2016 was implemented. If the variability of the predicted value from the actual does not exceed $5 \%$, then the model is taken as true. The calculations showed that the deviation of the predicted value (639143) from the actual (651925) was less than two percent (1.96\%), which confirms the efficiency of the model developed.

Next, a diagnosis was made of the economic policies of the regions according to the criterion of "average performance", by which the author understands the average value (arithmetic mean), which describes the degree of achievement of the result, taking into account the sign of completeness, that is, characterizing the average state of systems at a particular period in time. Based on the definition, the average performance formula for indicators affecting the GRP (see table 1) will be (formula 2):

$$
\bar{P}_{i}=\frac{\sum_{i=1}^{n} P_{i}}{n}
$$

where $\overline{\boldsymbol{P}}_{i}$ is the average performance for the corresponding indicator; $P_{i}-$ indicator of value; $n$ is the number of periods.

The author calculated the criteria $\bar{P}$ for 7 subjects of the North Caucasus Federal District, taking into account indicators affecting the GRP, which are presented in table 3. Based on the table, we conclude that the average performance

$\bar{R}$ of the indicator "The number of foreign citizens with a patent for labor activity" $X^{1}$ in The republics of Dagestan and the Stavropol Region exceed the average in the North Caucasus Federal District (NCFD), characterizes the achievement of the result in the subject at a high level, and only in the Republic of Dagestan does the indicator $X^{3}$ exceed the average for in the federal district, that is, indicators for other entities do not reach the optimum. The situation can be changed by creating favorable conditions for attracting foreign citizens, as well as increasing the effectiveness of management decisions in the distribution of financial resources of consolidated budgets, taking into account the degree of their influence on the GRP as a whole. Given the fact that the state budgets for 2019 and the planned for 2020 are focused on
TABLE III. THE ASSESSMENT RESULTS OF AVERAGE PERFORMANCE IN THE NORTH CAUCASUS FEDERAL DISTRICT BY INDICATORS $X_{1}$ AND $X_{3}$

\begin{tabular}{|l|l|l|l|}
\hline \multirow{2}{*}{ № } & \multirow{2}{*}{$\begin{array}{c}\text { Subject } \\
\text { (region) }\end{array}$} & $\begin{array}{c}|c| \\
\text { The number of } \\
\text { foreign citizens } \\
\text { holding a patent for } \\
\text { work (people) } \\
\text { X1 }\end{array}$ & $\begin{array}{c}\text { Costs of the consolidated } \\
\text { budgets of the constituent } \\
\text { entities of the Russian } \\
\text { Federation (million rubles) }\end{array}$ \\
\hline & NCFD & 3348.107 & X 3 \\
\hline 1 & S 1 & 5012.75 & 52886.77 \\
\hline 2 & S 2 & 1076.5 & 93210.25 \\
\hline 3 & S 3 & 2874.75 & 25682.08 \\
\hline 4 & S 4 & 3692 & 31131.75 \\
\hline 5 & S 5 & 2135.25 & 21634.73 \\
\hline 6 & S 6 & 717.75 & 26313.33 \\
\hline 7 & S 7 & 7927.75 & 70780.23 \\
\hline
\end{tabular}

As a result of the analysis, a number of criteria was determined that evaluates the development of the economic policy of the subjects from the point of view of the "performance" indicator.

Thus, an evaluation of regional economic policy with identification of key factors influencing it gives a more accurate description of regions from an economic point of view, allowing executive authorities to take into account the nature of modern processes for making effective management decisions and evaluate the main trends in the development of systems, which proves the importance and the validity of the proposed methodology.

\section{CONCLUSIONS}

A set of assessment tools has been developed taking into account the peculiarities of the regional economic policy of the subjects of a single federal district, which can be used in the analytical and practical activities of regional executive authorities.

\section{REFERENCES}

[1] G.I. Popodko and O.S. Nagaeva, "Management of the investment climate in the region", Basic research, 2019, vol. 5, 105 p.

[2] "On approval of the Fundamentals of the state policy for the regional development of the Russian Federation for the period until 2025", Decree of the President of the Russian Federation of 16.01.2017, vol. 13, pp.1-9 (Accessed: 25 September 2019).

[3] Yu.N. Gladky and A.I. Chistobaev, "Regional Studies: a textbook for academic undergraduate", 2018. 59 p.

[4] E. Yu. Marusinina, V.O. Moseyko, V.S. Epinina, and S.A. Korobov, "The strategic importance of the innovative potential of the regional economic system", Regional Economy, South of Russia, 2019, T. 7, vol. 2, pp. 102-113.

[5] S. S. Nosova, V. V. Ryabtsun, and A. N. Norkin, "Digital economy as a new model of modern socio-economic development of Russia", Economics and Entrepreneurship, 2018, vol. 3 (92), pp. 26-32.

[6] L.A. Valitova and V.L. Tambovtsev, "Priorities of regional policy in Russia: empirical analysis" [Electronic resource]. Available at: http://www.recep.ru/files/documents/policy_priorities_ru.pdf (Accessed: 09 October 2019). 
[12] G.Yannis, E. Papadimitriou and C. Antoniou, "Multilevel modelling for the regional effect of enforcement on road accidents", Accident analysis and prevention, 2007, vol. 39, pp. 818-825.

[7] E. G. Vasilieva, "Social Policy Performance Assessment: Regional practice", Power, 2018, vol. 12, pp. 29-34.

[8] A. I. Ostroumov and O. F. Ostroumova, "Regional policy in modern Russia: state and development trends", Historical, philosophical, political and legal sciences, cultural studies and art history. Questions of theory and practice, 2015, vol. 12 (62) part 3, pp. 119-123.

[9] H. Rojas-Romagosa, "Trade effects of Brexit for the Netherlands: Cpb background document" [Electronic resource]. Available at: https://www.cpb.nl/sites/default/files/omnidownload/CPB-ackgroudDocument-June-2016-Trade-effects-of-brexit-for-the-netherlands.pdf (Accessed: 19 September 2019).

[10] S. Dhingra, H. Huang, G. Ottaviano, J. Pessoa, T. Sampson, and J. Van Reenen, "The costs and benefits of leaving the EU: Trade effects", Economic Policy, 2017, vol.32 (92), pp. 651-705.

[11] J. Feyrer, "Trade and Income:Exploiting Time Series in Geography", NBER Working Paper [Electronic resource]. Available at: https://www.nber.org/papers/w14910.pdf (Accessed: 11 October 2019).
[13] S.Acharya, S.Morichi, and T. Yoshida, "Role of infrastructure investment in regional growth and dynamic simulation approach", Journal of the Eastern Asia Society for Transportation Studies, 1999, vol.3 (2), pp. 39-54.

[14] T. V. Mirolyubova and E. N. Voronchikhina, "Justification of economic policy priorities based on a structural analysis of the Gross Regional Product (on the example of the Perm Territory)", Bulletin of Perm University, Series: Economics, 2017, vol. 12 (1), pp. 91-109.

[15] N. V. Nepomnyashchaya, "Statistics: general theory of statistics, economic statistics. Workshop", 2019, 258 p.

[16] R. Sh. Khusnutdinov, "Mathematical statistics", 2019, 114 p.

[17] A. V. Zakharyan and N. A. Kolesnichenko, "The federal budget as an instrument of state policy and its orientation on social and economic policy", 2018, vol. 16, p. 64-72. 